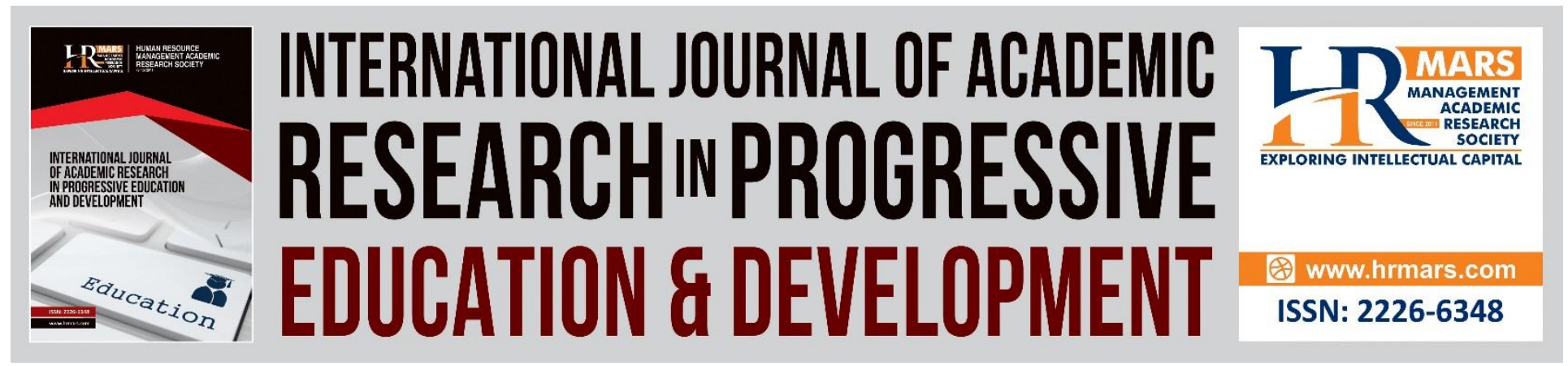

\title{
Reference Sources: The Future and Implication of Reference Services in Academic Library
}

Saiful Farik Mat Yatin, Nazatul Fida Kanan, Syafiqah Kamarudin, Zuhra Zainuddin

To Link this Article: http://dx.doi.org/10.6007/IJARPED/v7-i3/4366

DOI: $10.6007 /$ IJARPED/v7-i3/4366

Received: 12 June 2018, Revised: 28 June 2018, Accepted: 18 July 2018

Published Online: 25 July 2018

In-Text Citation: (Yatin, Kanan, Kamarudin, \& Zainuddin, 2018)

To Cite this Article: Yatin, S. F. M., Kanan, N. F., Kamarudin, S., \& Zainuddin, Z. (2018). Reference Sources: The Future and Implication of Reference Services in Academic Library. International Journal of Academic Research in Progressive Education and Development, 7(3), 278-290.

Copyright: (C) 2018 The Author(s)

Published by Human Resource Management Academic Research Society (www.hrmars.com)

This article is published under the Creative Commons Attribution (CC BY 4.0) license. Anyone may reproduce, distribute, translate and create derivative works of this article (for both commercial and non-commercial purposes), subject to full attribution to the original publication and authors. The full terms of this license may be seen

at: http://creativecommons.org/licences/by/4.0/legalcode

Vol. 7, No. 3, July 2018, Pg. 278 - 290

http://hrmars.com/index.php/pages/detail/IJARPED

JOURNAL HOMEPAGE

Full Terms \& Conditions of access and use can be found at http://hrmars.com/index.php/pages/detail/publication-ethics 


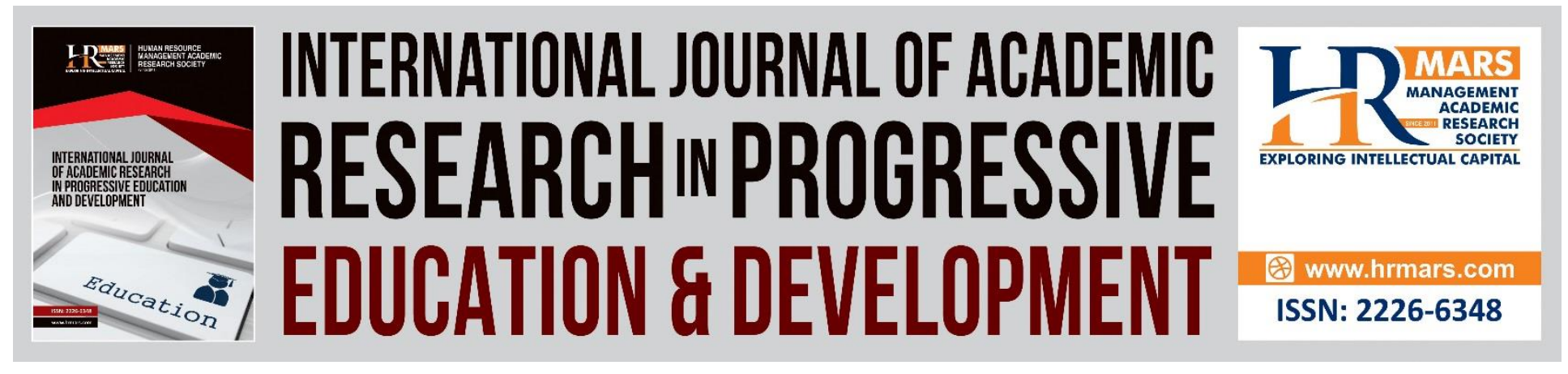

\title{
Reference Sources: The Future and Implication of Reference Services in Academic Library
}

\author{
Saiful Farik Mat Yatin \\ Nazatul Fida Kanan \\ Syafiqah Kamarudin \\ Zuhra Zainuddin \\ Faculty of Information Management, Puncak Perdana Campus, Universiti Teknologi MARA \\ (UiTM) Selangor, Malaysia \\ Email:farik@salam.uitm.edu.my,nfidak@gmail.com
}

\begin{abstract}
Academic libraries are facing tremendous changes in providing services due to the competition with digital collection that need to supply and to fulfil the demand from the users. As a librarian in references desk, the real role of the librarian itself might be misinterpreted by users. It is mostly happened in academic library especially small library in private institution. Reference services are heart of the library. It is starting point where the journey begins for the users. It works in both ways, which is functional as information counter and get free reference consultation service. Usually the reference services work in small group of peoples and individual. It usually happens in personal discussion between user and reference librarian. The appointed librarian will guide to the relevant sources with specific information needs for the users. Since, the invention of website is introduced; the information sources become variety in a different form. The question is suggestive to relevancy of reference librarian by providing direct access to information sources, whereas the users can get it by themselves. Meanwhile, on the library management side opinion the reference service department should blend together with the new changes of technology new form of information sources. Current digital library is more emphasize on the users to access of information itself. They more focus of user aspect know-how to retrieve the information, and forget the reference librarian part. Not all the information literacy can be taught and referred in digital way such as video tutorials, online courses, etc. The concept of digital library might be misinterpreted by few people and organization and missed out the role of librarian itself. Which is the librarian is the key of the changes of digital library, especially reference librarian, which is now they start to introduce the virtual reference services (VRS), and we need to comply with the standard of skill set. This paper is a review of several documents and analyse few online article, online journal of the issue in reference services.
\end{abstract}


INTERNATIONAL JOURNAL OF ACADEMIC RESEARCH IN PROGRESSIVE EDUCATION AND

DEVELOPMENT

Vol. 7, No. 3, July 2018, E-ISSN: 2226-6348 @ 2018 HRMARS

Keywords: Reference Services, Academic library, Library instruction, Information literacy, Virtual Reference Services (VRS), Library Science

\section{Introduction}

Library reference services usually provided at reference desk or information desk as a public service counter where professional librarians provide library users with direction to library materials, advice on library collections and services, and expertise on multiple kinds of information from multiple sources. It was a service provided by libraries whereby patrons are assisted in the location and retrieval of information relevant to their information needs. Reference services also refer the provision of information to people entering a library and requesting assistance from the library staff or in short personal assistance provided to library users seeking for information. Reference services, sometimes referred to as "reference and information services" refer to the personal assistance provided to users in the pursuit of information (Bunge, 1999). Provision of such personalized information services has remained the central theme of the library and information profession. The importance of these services grew over time with the introduction of new technologies and services in libraries. Bunge categorized reference services into three broad groups:

i. Information services that involve either finding the required information on behalf of the users, or assisting users in finding information;

ii. Instruction in the use of library resources and services (broadly defined as information literacy skills); and

iii. User guidance, in which users are guided in selecting the most appropriate information sources and services.

Arms (2000), while trying to answer the question "whether or not we need reference librarians in a digital library", pointed out that automatic tools are steadily reducing the need for reference librarians in fields like medicine that required a significant amount of intermediation in information searching. The essence of Arms' paper is that while computers can do a lot in performing most of the traditional jobs of reference librarians, their skills may be required in case of complex information searches. Arms, however, believes that there have been significant improvements in the end-user search facilities, provided by electronic database search services and Web search engines, and hence the need for human intermediaries in information searching has reduced significantly.

While reviewing the definitions of digital libraries, noted that "in general, researchers (who primarily come from computer science and/or engineering backgrounds) focus on digital libraries as content collected on behalf of user communities, while librarians focus on digital libraries as institutions or services"'. She further stressed that the current state of digital library research and development, especially in the USA, is influenced by the research definition of digital libraries.

Chowdhury and Chowdhury (2000) categorized online reference and information services into three broad groups: 
Vol. 7, No. 3, July 2018, E-ISSN: 2226-6348 @ 2018 HRMARS

i. Reference and information services from publishers, database search services, and specialized institutions.

ii. Reference services provided by libraries and/or experts through the Internet; and

iii. Conduct a search and find information through the Web

This paper is to identify the issue in reference services in academics' library and to find out the implication of references services in future

\section{Problem Statement - Issues in Reference Services}

Most of the questions asked at the reference desk were not reference questions

The librarian didn't set any criteria of user's question, but most frequent asked question can be solved within five minutes. It is more direct and general question and answers session. The question usually asked about technical part, such as problem with photocopier machine, reset the password, and sometimes borrowed the stationary tools from reference desk.

Users seemed confused about the role of librarians at the reference desk

The librarian has most of the times been mistaken as a support staff. The user's assumed all library staff plays the same role. Some of the user will asked the question in reference desk which is the question should be asked in circulation department, and the user hope that they will get the same answers as if they asked in circulation department.

\section{Multiple responsibilities}

The librarians who work at the reference services were also having many other task jobs. They are also an instructor in the Library Information Literacy Program to the user. While conduct the information literacy program to user, reference librarian also needs to update their collection development activity and liaison with academic staff or outreach program with each faculty.

\section{Discussions}

The Future of Reference Services

Usually the traditional reference service in library is located near with circulation department, as a front line and can be seen by user. The reference services can be described as information centre, where as the librarian in charge is a tour guide, front desk, receptionist for the library. He or she need to familiarize with the layout of the library, the collection, services in library and the main role is as a bridge between users and library organization, in term of improving themselves as main sources in institution. Now, the roles of the reference services were become more challenging due to demands for digital collection.

The reference services need to do some transformation in academic library, not just the physical but virtual too. As well as to remain the existing role, for example to advise the users in retrieving the collection in the library for their assignment, the method still remain the same but there is a need to apply in digital platform. The digital platform also helps the librarian to engage with user, and technology as tools of communication. The digital platform is not limited to email application but now in various channels such as instant messaging - WhatsApp and online chat in library portal which can be accessed through Smartphones and computers. However, audio and video 
DEVELOPMENT

Vol. 7, No. 3, July 2018, E-ISSN: 2226-6348 @ 2018 HRMARS

conferencing software also provides the Virtual References Services (VRS). In other words, the competency and job scope of reference librarian timely have changed with paradigm shift in library service.

\section{The Implication of Reference Services in Future}

At present, library instruction programs are offered in various formats. One-shot sessions are the most common method of providing library instruction to both undergraduate and graduate students. Teaching multisession library instruction modules has also been reported in literature. Based on statement above, they emphasize on providing the library instruction also known as library orientation in various format. Users have multiple choices whether to meet the librarian face-to-face or virtual. Reference librarian are required and need to equip themselves of skill sets of IT application and familiarize with the system in order to enhance the communication wise and effectively.

The growth of digital sources nowadays, the question has been raised up in library organization is, were the reference services needed? These some question they asking and reference services might lose the main purpose and role as reference desk. The organization should realize the effectiveness and reference services by adding the new value of reference services and not provoked the relevancy of their service. The digital sources growth with brand new of reference services too and will omit the traditional services slowly.

\section{Why virtual reference services?}

Recently, the waves of information searching are changing the pattern. The changes obviously through the concept of everything doing it by yourself searching. Few websites offer through advertising to answers the question. Most of the consultations sent through email, telephone and forms on the websites, and they can answer it within 48 hours. Compare to conventional way, most of the process time will take longer than we expected. The process will involve the librarian commitment itself, the resources and information exchange through collaboration partners. The virtual reference services become relevant in order to be part of the reference services itself and library services on the right internet platform.

The implementation of virtual reference services can be as an interactive remote reference service. The commercial reference services like "AskJeeves" have emerge in website and growing fast before 2010. This concept is highlighted question and answer session effectively. So, this concept can be implement in reference service, which is allow the users asked question and received the answers immediately and it is free from public information on the website. This kind of service can be one of the elements in reference desk, and will guide the users who don't have a time to come to library. However, this application is not for internal use only, but it is can apply to big community, for example become as medium of communication among collaboration partners and industry.

In conventional reference services, usually reference librarian able to respond immediately by one to one session mean users come to reference desk and asked the basic question. The concept is remaining the same, but we add new value in service which is in virtual reference services. The 


\section{INTERNATIONAL JOURNAL OF ACADEMIC RESEARCH IN PROGRESSIVE EDUCATION AND}

DEVELOPMENT

Vol. 7, No. 3, July 2018, E-ISSN: 2226-6348 @ 2018 HRMARS

users now have an option and alternative ways to choose whether to come to the library or have online session with expert librarian. The web is a platform to users and library to communicate and engage in information literacy, and research skill learning can be taught at the reference desk which is can be transformed in online environment, by allowing the users to get the information, for example library instruction, announcement, and reference services from hostel, residences, labs, or elsewhere. Library can be earned the benefit from technologies and this service model which is develop for the commercial industry at first, but now it is applicable for reference services. The evolution of e-commerce boosted by the development of system, which is provide live interactive customer service through web-based. This system shows that the interactive technologies will be useful for online live interaction reference.

These commercial reference services have several options for libraries to launching a virtual reference services. This service can reach a wide audience and users on an extensive range of a topic, problems and inquiries because of the Internet has expanded to the globally. So, libraries should set a clear idea about virtual reference services whether to serve among their own users or a broaden community. The system is offering whether the libraries can fully control to the system or can be supported by technical team and vendor. It is important to have their own VRS, and at the same time to increase the usage of a library service, for those who don't physically drop by the library.

The capabilities of virtual reference services, also allows the users, for example student, researcher, academician, be able and do the research, assignment from outside the library building and the university. This opportunity will give the benefits to university and college, to begin to offer to more courses and opportunities for those to choose as a distance learner and flexible learning program. So, it will lead to a new position as distance librarianships, that will functional as a library content developer, and there are more users actively used library service outside the library. In the technical part, VRS also need to offer access reference services for distance learners, as a convenient for remote user access to information itself such a part of service needs to be construct into the Internet infrastructure.

The idea of library as a convenient source is the key of library success. The word convenient is referring to the library which can reach out the users in their office, hostel and café, and help them to find the information, whenever they need it. It will successfully if the library itself capable to provide the quality information and services for information seeker.

\section{Suggestion and Recommendation}

Objectives of Virtual Reference Service

Transformation of library services is involving of providing excellent services by assisting the users with their educational and research sources. The reference librarian able to answers of the reference questions to users which is walk-in to the library and remotely through telephone, email and online services. Therefore, virtual reference service (VRS) has the following objectives:

i. To provide individual information support and instruction; 
Vol. 7, No. 3, July 2018, E-ISSN: 2226-6348 @ 2018 HRMARS

ii. To provide and maintain a proper collection of reference resources in both form which is print and electronic;

iii. To support the library users with locating the best quality sources of information;

iv. To help in marketing references and resources;

v. To serve as a public relations representative;

vi. Able to help for online searching;

vii. To assist the professional in term of activities, development and growth;

viii. To help in referral guiding process, forward the enquiry, or provide the user with URL link to advocacy or authorities websites;

ix. Educate users in term of concerning resources and research skills to create awareness to become information literate.

Virtual reference service is also known as digital reference service. It is new method that have become as value added for library service. It also an option for library service who is doing traditional practise at the library's reference desk, to consider the new technique to assist and consult the users locating, the sources of information. Virtual reference service is allowing the librarians and users to communicate each other whether it is in real time, or live or through email, telephone, video conferencing, and instant messaging. Virtual communication channel usually come in online chat, voice over IP, email and instant messaging. The communication through online is without being physically presence by both parties.

The commercial sector, program developer who has introduced the concept by offering the question and answer services. It is a big challenge for librarian to apply the new ways of providing services to the users. To librarian itself, this is show as a threat and opportunities which is beneficial for technologies development in library. By aligning the technologies to virtual reference service application, library service will become more effectively to meet the user needs, as well as the libraries on the web platform.

\section{Type of Virtual References Services}

Virtual reference service can be narrow down into two main types, email and chat in real time. The details of purpose these two main types as per below:

\section{i. Email}

This type of communication is the easiest way of the web platform. The user will send the reference query, to supplying whatever information form, whether it is physical or online, and information details that user feel necessary. The librarian may reply directly through email, phone call, fax, letter etc. There are two basic in email reference services:

Basic email. The service is designated a simple and easy email address provided on the library website. Email usually forms as wording in JPEG format. It is due to avoid the spammers and unnecessary email going in the VRS system. Usually, if the user wants to submit a question and enquiry, the users can click on the email link which is it will turn to the email launcher for example, Microsoft Outlook, Eudora etc. The user will fill out the email and sends it via the user's email. 
DEVELOPMENT

Vol. 7, No. 3, July 2018, E-ISSN: 2226-6348 @ 2018 HRMARS

Email reference service. The lack of email reference service is identified by numbers of communication difficulties. The users request might send in different language. It will take two to three days to interpret and understand the user inquiries. Even, in same language, the written communication might misinterpret by librarian itself. The question by user, sometimes need clarification with another department and superior. The librarian needs to attend each email, and settle it case by case. If the librarian wants to conduct reference interview with the user, they might face the difficulties to get respond for both parties.

ii. Chat in real time

Chat in real time is one the communication method that works live in current time. The expert librarian need to be ready and prepared for the inquiries and question. With complete infrastructure and tools such as hardware, software, and strong internet bandwidth is major successful reason to implement this method. Chats are possibly happened in instant messaging and video conferencing. User can choose whether to send short written message instantly or having live interaction session. The immediate respond by librarian will help the user to come back to use the library service. There are some of the software that allows the librarian to create and set the live and real time interaction with the users but with limited written message. The short written message will help the librarian to understand what the user requests are. Another type of chat in real time is open virtual reference room where is the library offer to multiple user to discuss and inquired at one time.

There are some ways, the program developer offers to run this type of service. Which are instant messaging, for example CompuServe Instant Messenger. For virtual reference room system also a solution such as can be tag together in Webmaster, and simple installation of software such as Anexa.com. Librarian will expand the various type of library service while applying live reference interaction, for example conduct the reference interview by exchanging information of short message and eliminate the problem of misunderstanding, mishearing what is said. This system is helpful for both parties to get better idea and clear picture and also save time. In addition, it's also suitable for the user who feels uneasy about communicate in person, face to face interaction, poor in oral and verbal communication, and also suitable to whom may not be able to visit library because of facing some difficulties.

\section{Role of Virtual Reference Librarian}

The librarian, who is train in traditional way, will be equip with the knowledge and skills of acquisition, organization, retrieval and dissemination of information. The traditional practice of librarianship should be remaining, and add on with new skills in term of information technology skills. The librarian role will remain especially the selection of resources, providing access, for example library instruction, consultation for researcher and assisting the user to interpret the resources. The issues for new librarian facing nowadays, is virtual library environment, which is related new technologies and blends the collection in digital forms. The new techniques are suitable to implement new forms of information resources and services. To supplying information access, the virtual reference librarian must consider the environment and ambiance of any digital resources. The justification of hardware and software is considered in terms of availability and ability that can be use in effective way. 
The virtual library environment also needs to consider new technical set of competencies, for librarians which were not previously required. Now the basic skills such as creating web pages, building and maintaining computer networks, designing search interfaces are needed for today's library employment market. Along with the need for technical skills the ability 'to plant a level of comfort with change is also required. One characteristic of the virtual library, which is librarians must full fill, is the rapidly transform, changing and evolving librarianship nature of the environment. This environment is subject to immense change very quickly and a main role for the librarian in the future will be the ability to adapt and to work effectively in such an environment.

\section{Concept of virtual reference service}

The concept of virtual reference service is related to technical part in implementing this method in library. As we mentioned before, the infrastructure is a pillar and its supported by good internet networking, software and technical staff. Virtual reference refers to a network expertise and the resources placed for someone who is looking for it in an online environment. This service allows the users interaction to submit question and answer through internet and other electronic forms. Furthermore, to answering the question, expert people such as librarian and technical staff need to work together by providing information in website. The expert must be able to identify frequent asked question by users. By providing the enough referral users can view online or able to print out the information, and will support the information literacy. A virtual reference service transaction will include with four major elements:

i. User;

ii. Website interface (Web form, email address, online chat, video chat);

iii. Electronic resources (CD-based resources, web resources, digitized collection materials); and iv. Information professional

\section{Nature of virtual reference services}

In a nutshell, virtual reference services are depending on internet-based reference service which fully conducted through online. It is one of popular an extension of reference service provided by library professional. All the query and question will have asked through online. The online environment allows the users and library professional interact live, whether it is virtual, digital, real time or so called synchronous virtual reference. Another terminology usually been used is asynchronous virtual reference, which is the communication usually sent, received and reply at different time. Normally, the librarian will follow up through telephone, fax, and regular email. Some people considered these modes of communication which is not virtual.

\section{Advantages of networked reference services}

The greatest advantage in using networked reference services in the libraries is the ability to connect with library users. The networking allow user to stay updated on library services and have all the references and resources they need without having physically go to the library. Reference service networking also allows libraries to interact with user through discussion boards and comments on services through library website walls. The networking not only allows the library user to reach out to libraries but also allow libraries to reach out to their users. User can 


\section{INTERNATIONAL JOURNAL OF ACADEMIC RESEARCH IN PROGRESSIVE EDUCATION AND}

DEVELOPMENT

Vol. 7, No. 3, July 2018, E-ISSN: 2226-6348 @ 2018 HRMARS

leave feedback for libraries and can make suggestions to improve the quality of reference services.

Another advantage is the library can post images of reference books or articles for discussion groups and researchers or post pictures and videos of the latest library events and reference services. Most of all, the reference service networking sites allow library users to find information they needed through resources and reference collection in any library of their choice.

Disadvantagesof networked reference services

But, reference service networking does not come without disadvantages. The digital sites need software's, applications and electronic gadgets so that the online information and knowledge about reference service can be access and use conveniently. If the library lacks of electronic facilities because of low budget, then the networking reference service cannot be applied accordingly.

Some low budget libraries must decide whether they want to utilize this new technology and, if so, they should make decision which networking opportunities are best for their library and the process will take more time.

Another disadvantage on applying networking reference service when the online service cannot reach the information satisfaction. The interaction with the reference librarian through e-mails, chats, video chats, Skypes or video conferencing in answering reference queries from users at a distance not always can provides the required answers. Some of the librarians are concerned with the video quality and the user's virtual experience when compared with face-to-face interactions. The user-librarian transaction and question negotiations tend to be more straightforward when the user is physically present at reference service desk.

Another network disadvantage regarding reference services that is depending on the stability of the network connection or the poor quality online when the user using low-bandwidth connection. Both librarians and users experience frustration with bad connections, bad software performance or not-working websites features. Some users have difficulties in understanding librarian explanations.

Future Reference Services Directions: Library Systems and Services

The future of reference services and the direction where should be going, it is must work for the infrastructure and staff. The infrastructure is referring to the academic library and staffs are referring to the skills and knowledge development. It is not one-day task to complete it, but it is continuously until it able to achieve certain benchmark and level. When we talk about the library, the direction should be parallel with institution vision. We can't compete and compare the traditional and modern facilities, which are dealing with technology. Yes, we remain the existing task and responsibility but we should think how to blend it with technology. Today, we usually improved the way to do things and we offer services to others. For example, we provide staff to explain or to guide the users about library layout. But now, we can provide the same services with 14-inch touch screen TV with directory applications. Reference desk also need to and ready to change to become current and relevant reference desk librarian. For change something new, sometimes it will lead about unexpected result. It is important that we work as a team to effect necessary change. The staff must constantly promote the idea that the change is important and it is required in order not to pertinent in term references services. The staff should take note the user feedback which is important. The changes will lead the positive vibe in the library and users feel more comfortable. Reference desk librarian should have a mind-set of change in term of the 


\section{INTERNATIONAL JOURNAL OF ACADEMIC RESEARCH IN PROGRESSIVE EDUCATION AND}

DEVELOPMENT

Vol. 7, No. 3, July 2018, E-ISSN: 2226-6348 @ 2018 HRMARS

involvement, leadership, digital transformation, information and technology literacy. The reason for these changes is not just to ensure that the staff familiar with services but can fully benefit to them. In general, communication skills and activities deserve more attention for traditional academic library. These changes post and interesting questions come into their minds, is all about developing staff at academics' libraries. As rapid changes in both information and education surrounding it will give impact to staff roles. The reference desk librarian should be able to define and embrace new roles as at the same time to develop existing ones. The contribution of energy, idea, work load, sometimes is just behind the scene and it is unheard. So they need to voice out to university leadership and funding bodies to understand the core value and contribution of libraries.

While discussing the technical part of virtual reference services, one of the commonly software has been introducing since 2000, is virtual reference toolkit software which is as a host to reference network. There is no complete set of software, to install and setup the whole process for virtual reference services. The single software will be install and integrate with online network and can be used 24/7 a week. LSSI as known as library system and service will in charge the system integration, in order to connect with distance learner. The workspace for reference librarian need to equip with suitable tools, for them to connect and conduct live online reference session.

\section{Conclusion}

To accessing information resources nowadays much easier. Mostly information can be accessed in online platform. Databases now more widely in term of collection such as world wide web, full text periodical and now, information accessing going up another level has revolutionized to virtual reference services. The information overload has given new era and transition to library reference service. Evaluating information sources and integrate with reference librarian as an information agent plus the good understanding and skills of the reference and information services.

Online resources have increased in popularity among information seeker, as for individuals and organizations that have connected with the global network. Thousands of company and organization have transform to internet-based information, which is as an effective and cost efficient for the company. Different from traditional and conventional operation and company communication method, most of them realize the importance to expand their services by interacting their customers and quickly respond to inquiries through internet.

\section{References}

Applegate, R. (2008), "Whose decline? Which academic libraries are 'deserted' in terms of reference transactions?", Reference and User Services Quarterly, Vol. 48 No. 2, pp. 176-89.

Arndt, T.S. (2010), "Reference service without the desk", Reference Service Review, Vol. 38 No. 1 p. 71-80. 
Vol. 7, No. 3, July 2018, E-ISSN: 2226-6348 @ 2018 HRMARS

Arms, W.Y. (2000), "Automated digital libraries: how effectively can computers be used for the skilled tasks of professional librarianship?", D-Lib Magazine, Vol. 6 No. 7/8, pp. 191-8

Bandyopadhyay, A. and Byrnes, M.K.B. (2016), "Is the need for mediated reference service in academic libraries fading away in the digital environment?", Reference services review, Vol. 44 No. 4, p. 596-626.

Bunge, C.A. (1999), "Reference services”, Reference Librarian, Vol. 66, pp. 185-99.

Chowdhury, G.G. and Chowdhury, S. (2000), "An overview of the information retrieval features of twenty digital libraries", Program, Vol. 34 No. 4, pp. 341-73.

Deng, S. and Zhang, Y. (2015), "User perceptions of social question and answers websites for library reference services: A content analysis", The Electronic Library, Vol. 33 No. 3, p. 386399.

Flanagan, P. and Horowitz, L.R. (2000), "Exploring new service models: can consolidating public service points improve response to customer needs?", The Journal of Academic Librarianship, Vol. 26 No. 5, pp. 329-38.

Foster, N.F. (2007), "The mommy model of service", in Foster, N.F. and Gibbons, S. (Eds), Studying Students: The Undergraduate Research Project at the University of Rochester, Association of College and Research Libraries, Chicago, IL, pp. 72-8.

Jastram, I. and Zawistoski, A. (2008), "Personalizing the library via research consultations", in Steiner, S.K. and Madden, M.L. (Eds), The Desk and beyond: Next Generation Reference Services, Association of College and Research Libraries, Chicago, IL, pp. 14-24.

Johnson, B.L. and Alexander, L.A. (2008), "Reaching beyond the walls of the library", in Steiner, S.K. and Madden, M.L. (Eds), The Desk and beyond: Next Generation Reference Services, Association of College and Research Libraries, Chicago, IL, pp. 25-37.

Kuchi, T., Mullen, L.B. and Tama-Bartels, S. (2004), "Librarians without borders: reaching out to students at a campus centre", Reference and User Services Quarterly, Vol. 43 No. 4, p. 310.

LaGuardia, C. (2003), "The future of reference services", Reference Services Review, Vol. 31, November, No. 1, p.39-42

Nassar, A. (1997), "An evaluation of the Brandeis model of reference service at a small academic library", The Reference Librarian, No. 58, pp. 163-76.

Pinto, M. and Manso, R. A. (2012) "Virtual references services: defining the criteria and indicators to evaluate them", The Electronic Library, Vol. 30 No. 1, p. 51-69. 
INTERNATIONAL JOURNAL OF ACADEMIC RESEARCH IN PROGRESSIVE EDUCATION AND

DEVELOPMENT

Vol. 7, No. 3, July 2018, E-ISSN: 2226-6348 @ 2018 HRMARS

Zamostny, J. (2008), "Sheep in Wolves' clothing: undergrads at the reference desk", Library Journal, Vol. 133 No. 11, p. 92. 